\title{
Managing Strategic Partnerships with Universities in Innovation Ecosystems: A Research Agenda
}

\author{
Giovanni Schiuma ${ }^{1, *}$ and Daniela Carlucci ${ }^{2}$ \\ 1 Department of Mathematics, Computer Sciences and Economics (DIMIE), University of Basilicata, \\ 85100 Potenza, Italy \\ 2 Department of European and Mediterranean Cultures, Environment and Cultural Heritage (DICEM), \\ University of Basilicata, 75100 Potenza, Italy; daniela.carlucci@unibas.it \\ * Correspondence: giovanni.schiuma@unibas.it
}

Received: 30 May 2018; Accepted: 25 June 2018; Published: 28 June 2018

\begin{abstract}
This paper proposes a research agenda for understanding how to establish and develop strategic partnerships with universities in innovation ecosystems, aimed to support the development of companies' entrepreneurial and innovation development capacities. In particular, the paper suggests an integrated model to explore how universities and companies establish, manage, and assess collaborative relationships to foster entrepreneurial and innovative capacity. The framework identifies four fundamental dimensions that characterise the role and function mechanisms of successful collaborative relationships: (1) the entrepreneurial learning network dynamics and the transformational patterns affecting the development of entrepreneurial capital of university-based innovation ecosystems; (2) the role and features of the university-based organisational units to support companies' entrepreneurial and innovative development in innovation ecosystems; (3) the organisational models and factors influencing a company's capacity to establish successful partnerships with universities and to develop entrepreneurial and innovative capabilities; and (4) the approaches, models, and tools that can support universities and companies to design, implement, and assess partnerships and initiatives aimed to develop entrepreneurial and innovative capabilities.
\end{abstract}

Keywords: strategic partnerships; universities; innovation ecosystems; companies' entrepreneurial and innovative development capacities

\section{Introduction}

The relevance of the collaborative relationships of universities with companies and the role of universities in the development of innovation ecosystems have attracted considerable attention in the economic and management literature [1-5]. The continuous expansion of universities has opened new spaces and possibilities as universities are interconnected with a number of forms of ecosystems [1], such as, particularly, the innovation ecosystems. Despite the acknowledgement of the relevance of universities in innovation ecosystems, the understanding of how to establish and run strategic partnerships between universities and companies as well as how to manage and assess initiatives to foster companies' entrepreneurial and innovation development capacities are still open challenges.

For this reason, a key research question to be addressed is the following: How can strategic partnerships with universities be established and managed in innovation ecosystems in order to develop companies' entrepreneurial and innovation capacities? This research question has a general validity. However, it is particularly relevant for those innovation ecosystems located in regions characterised by a development delay. Indeed, innovation and entrepreneurship represent two core fundamental dimensions to drive growth and sustainability of regions and their industry clusters of companies. They represent an imperative for all organisations and particularly for those companies 
located in less-developed areas, such as the regions of southern Italy, that struggle to find ways to be competitive. Despite the number of European, national, and regional policy initiatives aimed to support the development and adoption of innovations, mostly, the companies of these innovation ecosystems show a lack of an inner capacity for innovation and have weak ties with research institutions.

In this study, it is assumed that the development of an innovation ecosystem, although related to the texture of the virtuous dependent and interdependent relations shaped within the ecosystem by all its stakeholders, is strongly affected by the strategic partnerships of universities with companies (both new ventures and existing enterprises). In particular, while companies are the main actors of entrepreneurial and innovative dynamics, universities play a critical role for the creation of a "platform" and "atmosphere" for entrepreneurial and innovative initiatives to be catalysed and nurtured. From this perspective, collaborative university-company relationships are indeed critical components of the development of an innovation ecosystem, having significant spillover effects and being positively correlated with the innovation output [6]. Therefore, the management of partnerships with universities represents a strategic approach for developing companies' entrepreneurial and innovative capacities, which, in turn, affect the growth of an innovation ecosystem.

From this perspective, this paper focuses on university-company relationships and proposes a research agenda and questions about the development of university-company partnerships in innovation ecosystems. In doing this, it suggests an integrated model to explore how universities and companies establish, manage, and assess collaborative relationships to foster entrepreneurial and innovative capacities.

This model combines four fundamental research perspectives as follows: (1) the entrepreneurial learning network dynamics and the transformational patterns affecting the development of entrepreneurial capital of university-based innovation ecosystems; (2) the role and features of the university-based organisational units to foster companies' entrepreneurial and innovative development in innovation ecosystems; (3) the organisational models and factors affecting a company's capacity for establishing successful partnerships with universities in order to develop entrepreneurial and innovative capabilities; and (4) the approaches, models, and tools that can support universities and companies to design, implement, and assess partnership initiatives to foster the development of entrepreneurial and innovative capabilities.

\section{The Role of Universities in the Development of Local Innovation Ecosystems and Innovative Entrepreneurship}

\subsection{Innovation Ecosystems and Innovative Entrepreneurship}

The relevance of the relationships between universities and companies as well as the role of universities in the development of local innovation ecosystems has attracted great attention in the economic and management literature [1,3-5]. An innovation ecosystem is acknowledged as an enabling infrastructure in which different actors with different backgrounds and experiences dynamically interact by promoting processes of knowledge creation, diffusion, and absorption. Malerba [4] suggests that an innovation ecosystem can be interpreted as an environment populated by various business actors, a network of collaborations, and institutional settings that impact on the creation of innovative and technology-driven entrepreneurship. In this view, the innovation ecosystem perspective highlights the opportunity of activating a nonlinear process of co-creation as a strategic factor that catalyses and integrates the vertices of the so-called "knowledge triangle" [7], i.e., research, innovation, and higher education.

A useful framework for capturing the complex composition of actors and processes taking place in an innovation ecosystem is identifiable in the Triple Helix model [8-10]. Starting from its first conceptualisation, the Triple Helix framework identifies in governments, academia, and industries the main macrocategories of actors behind the processes of regional development and competitiveness, based on knowledge development and innovation. Shaping the boundaries of the Triple Helix model, the innovation ecosystem includes the entrepreneurs and their organisations (which represent the primary 
actors of the innovation and users of the knowledge), the research institutions and the universities (considered as the main knowledge producers), the financial institutions that facilitate the innovation among the enterprises, and all those dynamic factors enabling the cooperation, the mobility, the exchange of knowledge, and the social interactions [11].

An innovation ecosystem is locally structured, but it is also globally branched through the network of individuals, researchers, and entrepreneurs involved in solving shared problems and emerging societal challenges. Therefore, it acts locally but its implications and impacts can have global magnitude.

An innovation ecosystem is identifiable as a system of actors where new ideas are generated, and organisations are engaged in transformation and development processes. It is possible to identify at least three main attributes that characterise an innovation ecosystem: (i) strong entrepreneurial culture and behaviours, able to stimulate creativity and innovative capacity; (ii) continuous flow of ideas and people moving easily from one organisation to another, from research centres to enterprises and vice versa, and the diffusion of an entrepreneurial culture; and (iii) informal and formal networks of learning relations operating as transmitters of information, ideas, and knowledge.

The innovation ecosystems play a fundamental role in boosting innovative entrepreneurship by creating new knowledge, by applying novel combinations of existing knowledge, or by recombining existing knowledge in new ways [11]. This highlights the relevant contribution that innovation ecosystems can provide in creating innovative entrepreneurship by leveraging virtuous processes of knowledge creation, absorption, and diffusion to support the rise of new entrepreneurial ventures as well as the development of the innovation capacity of existing organisations in terms of new products, processes, market, and organisational settlements. As argued by [4], this is a crucial step for economic progress and the competitiveness of regions and countries.

Indeed, innovative entrepreneurship can be defined as the process emerging from the mixture of individual talents and skills—such as creativity, instinct, courage, capabilities of vision, practical sense, passion for innovation and challenges, passion for experimentation, and leadership-as well as of technological, managerial, and financial resources, together with the comprehension and satisfaction of the market's needs $[12,13]$.

Innovative entrepreneurship is a fundamental driver for the general enhancement of the socio-economic conditions of territories and is a nonlinear process, founded on a set of relationships between a wide large community of stakeholders; as such, it represents a catalyst for the development of local companies' entrepreneurial and innovation capacities [14].

In the last decade, innovation ecosystems and the related innovative entrepreneurship have been greatly affected (and continue to be affected) by the digital transformation of the world and the wide spread of new advanced technologies that are increasingly permeating and modifying all sectors of human life.

The rise of a massive quantity of heterogeneous, structured and unstructured data-labelled as big data-combined with the technological and digital transformation trends, is radically reshaping value creation, delivery, and capture in the economy and society $[15,16]$.

New technologies, such as intelligent agents, robotics, machine learning, artificial intelligence, block chain, sensors, virtuality, 3D printing, and augmented reality, just to name a few, are greatly influencing the conception, execution, and renewal of entrepreneurial and innovation processes.

Thus, it is not surprising that nowadays the notion of innovative entrepreneurship can be also denoted "technology entrepreneurship". Technology entrepreneurship can be understood as the capacity, competence, and attitude to transform new ideas, technologies, and inventions into commercially viable products and services to create economic and social value through innovative business models [17-21].

The emphasis on technology features of entrepreneurship is particularly important due to the institutional debate on the smart specialisation of the regions, which is considered as a core process of the local socio-economic development of specific regions [22]. 
Moreover, the technology-driven view of entrepreneurship is coherent with the mainstream assumption that technologies are important factors for stimulating and activating innovation processes [23-25] as well as with the current emphasis placed on the adoption of key enabling technologies (KETs) acknowledged as drivers of innovation, R\&D, and business model transformations of companies and clusters.

\subsection{Universities: Key Actors for the Development of Local Innovation Ecosystems and Innovative Entrepreneurship}

Universities, as knowledge-intensive producers, play a critical role in the development of local innovation ecosystems. They support knowledge-based processes for the entrepreneurial and innovation development capacities of both new ventures and existing companies by generating, transferring, brokering, codifying, and diffusing specialised knowledge and culture. Accordingly, universities are recognised as a source of graduates and talents with specialised knowledge as well as of ideas, knowledge, and skills for company research and development; and, broadly, of the development of local stakeholders' culture and learning dynamics for sustainable growth.

Recently, a rising number of universities have started to play a key role in creating innovations out of new ventures and spin-offs with the collaboration of science parks, technology transfer offices, incubators, and innovation centres or accelerators [25]. Some universities have established dedicated entrepreneurship centres aimed to stimulate enterprise and entrepreneurship activities [26,27]. Their aim is to support a broad spectrum of learning and research initiatives, providing resources for various internal and external entrepreneurial educational programs as well as supporting entrepreneurship-driven innovation and social community development $[27,28]$. The scope is the creation and diffusion of entrepreneurial mindsets and behaviours as well as the nurturing of successful entrepreneurship development [29-31].

The development of entrepreneurship centres within universities plays an important role as a catalyst of local innovation and entrepreneurial ecosystems [27]. In particular, within a university, an entrepreneurial ecosystem can be interpreted as collaborative and holistic activities focusing on the promotion of entrepreneurial mindsets, which is guided by a clear institutional strategy [27].

An entrepreneurial ecosystem based on a university has many dimensions and includes entrepreneurship courses, incubators, accelerators, grants, and business plan competitions [32].

An important dimension of the success of such an entrepreneurial ecosystem is the stakeholders' involvement in creating a supportive environment for fostering and encouraging entrepreneurial attitudes for the success of entrepreneurship development [29].

For many companies, universities represent an important innovation partner and the successful cases of the Silicon Valley, Block 71 in Singapore, and Kendall Square in Cambridge (MIT), to name the most visible examples, represent evidence of the critical role that universities can play in the growth of an innovation ecosystem and the enhancement of organisational entrepreneurial and innovation capacity. Indeed, the increasing need of many companies to look to so-called "open innovation", to enhance their internal capacity for innovation and development, acknowledges universities as catalysers of the development of local innovation ecosystems. This means that, increasingly, the creation of strategic partnerships between universities and companies of a local innovation ecosystem is recognised as a critical driver for the development of organisational entrepreneurial and innovation capacity. This is particularly important for those knowledge-based entrepreneurship ecosystems that are characterised by technology-intensive operations as well as product and service production.

Further important elements of entrepreneurial ecosystems based on universities are the role and the impact of digital technology as well as the ways through which all the actors of the ecosystem are connected with each other, socially and physically. 
3. Defining a Research Agenda to Understand How Companies and Universities Can Establish Strategic Partnerships for Organisational Entrepreneurial and Innovation Capacity Development

Despite the acknowledgement of the relevant role played by universities in innovation ecosystems and entrepreneurship development, the understanding of how to establish and run strategic partnerships between universities and companies as well as how to manage and assess initiatives to foster companies' entrepreneurial and innovation development capacities are still open challenges. For this reason, as mentioned in the introduction, this research aims to address the following key research question: How can companies establish and manage strategic partnerships with universities in order to develop organisations' entrepreneurial and innovation capacities?

This research question, although it has a general validity, is critical for those innovation ecosystems located in regions characterised by a development delay. Indeed, innovation and entrepreneurship represent two core fundamental dimensions to drive the growth and sustainability of regions and their clusters of companies. They represent an imperative for all organisations and particularly for those companies located in less-developed areas, such as the regions of southern Italy, that struggle to find ways to be competitive. Despite the number of European, national, and regional policy initiatives aimed to support the development and adoption of innovations, mostly, the companies of local innovation ecosystems lack an inner capacity for innovation and have weak ties with research institutions. These companies can surely rely on both internal and external capacity to innovate [33]. However, while large companies have an internal structure to support their innovation processes and relations with universities, small-medium organisations generally lack dedicated organisational units and infrastructure to foster their innovations dynamics. On the other hand, the access to external innovation opportunities requires understanding as well as internal knowledge in order to absorb and apply innovative practices and solutions.

The context and the proximity represent further important dimensions explaining the ability of companies to develop and deploy internal and external innovation capacity. Indeed, companies operating in rich-knowledge local contexts can benefit from innovation osmosis mechanisms based on knowledge diffusion and spill-overs, whereas companies with size constraints, that are located in less-developed economic areas, and have a shortage of financial and intellectual capital, i.e., human, relational, and organisational capital, have difficulties tapping into an innovation capacity that can foster their development. The latter are some of the main features of the Small-Medium Enterprises (SMEs) mostly characterising the local innovation ecosystems in southern Italy. In this context, it is of fundamental importance to understand how companies/clusters, characterising the development of a local innovation ecosystem, can establish and manage constructive and productive collaborations with universities. In the last years, Italian universities have identified as one of their strategic goals the so-called "third mission", aiming at engaging with local stakeholders for entrepreneurship, innovation, and cultural and social growth, but there is still a strong need to understand how to establish and develop strategic partnerships matching the innovation needs of local innovation ecosystems' and universities' initiatives aimed to foster innovation and organisational development.

Therefore, it is relevant to develop a framework that can explain and inform, both for descriptive and normative purposes, how successful universities' partnerships with local innovation ecosystems can be developed. This involves tapping into some key areas of investigation that are aligned with the leading research question.

\section{Disclosing How Companies and Universities Can Establish Strategic Partnerships: Some Key} Research Questions

Getting a better understanding about how companies and universities can establish strategic partnerships for organisational entrepreneurial and innovation capacity development entails tapping into six areas of investigation that are aligned with the abovementioned leading research question. These areas encompass many research questions, as follows. 
First, what are the value goals characterising the local innovation ecosystems' partnerships with universities? The companies of an innovation ecosystem can be motivated by a wide range of reasons to engage in collaborations with universities. It is possible to distinguish multiple goals motivating companies to establish collaborative relationships with universities, such as problem-solving; talent scouts; research collaborations; technology-knowledge-intensive transfer and development; exposure to start-ups; reputation; access to intellectual property; organisational learning and development; and foresight and identification of industry gaps and opportunities. For this reason, it is fundamental to understand what kind of specific benefits organisations are looking for from the collaboration with universities. Companies of a local innovation ecosystem have to elucidate their collaboration goals and align them with the company's strategic value creation intent.

Second, what are the entrepreneurial learning dynamics and the transformational patterns affecting the growth of entrepreneurial capital within the university-based innovative entrepreneurship ecosystems?

The "knowledge intensive" nature of entrepreneurial capital, defined as a multiplicative function of entrepreneurial competence and entrepreneurial commitment [34], requires the activation of entrepreneurial learning dynamics with the network of actors continuously interacting among them. Thus, any strategies devoted to supporting and sustaining entrepreneurial capital growth should be based on both developing entrepreneurial competence and encouraging entrepreneurial commitment through the activation of different entrepreneurial learning processes, always dynamic and nonlinear. These processes appear to be at the core of the evolving role of universities within the innovative entrepreneurship ecosystem. The study of how to make a university more entrepreneurial within the ecosystem is part of a number of transformative trends of higher education and research institutions towards a networked, ubiquitous, pluralistic model. Consequently, it becomes necessary to design a "transformation pattern" aimed to support the "evolutionary" development made by different enabling system (vision, actors/stakeholders, needs, cultures, industries, etc.) and strategic planning phases with the ultimate perspective of contributing to the growth of entrepreneurial capital.

Third, what are the main collaboration formats to put in place to establish collaborations between the innovation ecosystems and universities? Indeed, the selection of the right collaboration format is critical for the success of the partnerships with universities. Companies sponsoring research projects represent the traditional format. However, in the last years, a variety of formats have been explored and deployed by companies and universities seeking the establishment of more effective collaborations within local innovation ecosystems. Examples can range from contract research with research labs, individual company employees embedded in a research centre, consortia memberships or alliances, joining co-created research centres and/or programs, open calls for grant proposals in specialised research areas, student/company hackathons and idea contests, collaboration on publicly funded projects, fellowship programs, and jointly sponsored conferences and workshops, creating a campus living lab—such as smart building systems, international innovation exchange initiatives, and fellowship programs funding $\mathrm{PhD}$ students and postdoctoral researchers. The collaboration format depends on the targeted goals of the company-university collaboration.

Fourth, what are the forms of engagement between start-up firms and innovation ecosystems that universities can promote and facilitate? Companies can engage with start-up firms through different forms. On the basis of the nature of the start-up enterprise, universities can support identification and connection with student-led start-ups (for example, by means of business plan competitions or student accelerators) with lab-based start-ups, where the relation has to take into account consideration of intellectual property and the engagement of faculty members, and with proto-start-ups, i.e., student teams working on innovation ideas.

Fifth, what people, processes, and organisational structures support the working mechanisms of universities' partnerships with innovation ecosystems? In order to support the activities of universities, it is important to understand their internal structure and processes. This poses questions about the university units' structures that enable effective collaborations with local innovation ecosystems as 
well as about the companies' unit and organisational context. This requires an understanding of the competencies that managers need, and of the processes that are best suited to fostering the innovation development capacity of the local innovation ecosystem. This needs to draw from an analysis of the key knowledge-based mechanisms, such as knowledge brokerage, knowledge transfer, knowledge sharing, and knowledge creating, driving the development of the company's innovation capacity. Universities can be a strategic actor in each phase of the innovation process: from idea generation to product launch when considering new product and service development, and from seed to sustained growth in the case of new innovative businesses. Each phase demands different capabilities and, as a consequence, different organisational structures and interorganisational relations to generate, sustain, and exploit these capabilities.

Sixth, what performance measurement systems and indicators are most useful for assessing universities' activities for the innovation ecosystem development? Traditional key performance indicators suggested by the management literature focusing on university-industry collaborations include in the assessment panels measures such as cash investment, number of joint projects initiated/developed per year, number of students hired, number of patents or licensing agreements, amount of public funding leveraged, effectiveness and efficiency of projects, number of faculty members and students involved in projects per year, number of ideas that turn into product development, and number of investments in start-up firms. The challenge is to develop an assessment framework including qualitative and quantitative indicators that can comprehensively evaluate collaborations of innovation ecosystems with universities and drive their management.

\section{Investigative Dimensions for the Definition of an Integrated Model to Understand Strategic Partnerships with Universities in Innovative Ecosystems}

The understanding of the strategic partnerships with universities in innovative ecosystems requires the definition of an integrated model which can support-both for descriptive and normative purposes-the management and assessment of collaborative relationships of universities with companies aimed to foster the development of companies' entrepreneurial and innovative capabilities.

For this reason, it is important to focus the analysis on four combined research perspectives that take into account the abovementioned key areas of investigation and translate in operative terms the research agenda (see Figure 1).

In the following, each research perspective is discussed. For each research perspective, Table 1 reports the related key research question, the sub-research questions, and the main achievable research results.

The first perspective is "Networking dynamics", i.e., the understanding of the entrepreneurial learning network dynamics and the transformational patterns affecting the development of the entrepreneurial capital of university-based innovation ecosystems. The focus is on the dimension of the dynamic and multi-actor environment in the innovation ecosystems as well as on the activities of research, higher education, and innovation that co-exist for generating entrepreneurial capital. The "knowledge-intensive" nature of entrepreneurial capital, defined as a multiplicative function of entrepreneurial competence and entrepreneurial commitment [34], requires the activation of entrepreneurial learning dynamics with the network of actors continuously interacting among them. 
Table 1. Research perspectives, key and sub-research questions and main achievable research results.

\begin{tabular}{|c|c|c|c|c|}
\hline Perspective & Key Research Question & Sub-Research Questions & Main & n Research Results \\
\hline $\begin{array}{l}\text { Networking } \\
\text { dynamics }\end{array}$ & $\begin{array}{l}\text { What are the learning network } \\
\text { dynamics characterizing the } \\
\text { entrepreneurial capital } \\
\text { development of university-based } \\
\text { innovation ecosystems? }\end{array}$ & $\begin{array}{l}\text { (RQ1) What are the characteristics of entrepreneurial capital } \\
\text { development and how do we measure it? } \\
\text { (RQ2) What are the entrepreneurial learning processes } \\
\text { distinguishing the university-based network dynamics of } \\
\text { an innovation ecosystem? } \\
\text { (RQ3) What are the university-based strategies and } \\
\text { management actions to foster entrepreneurial capital within } \\
\text { innovation ecosystems? }\end{array}$ & $\begin{array}{l}\text { (i) } \\
\text { (ii) } \\
\text { (iii) } \\
\text { (iv) }\end{array}$ & $\begin{array}{l}\text { Identification of main dimensions and characteristics of the } \\
\text { entrepreneurial capital development of university-based } \\
\text { innovation ecosystems; } \\
\text { Assessment of entrepreneurial capital development of } \\
\text { innovation ecosystems; } \\
\text { Taxonomy of entrepreneurial learning dynamics of } \\
\text { university-based innovation ecosystem networks; } \\
\text { Definition of a framework to design, implement, and assess } \\
\text { university-based strategies and management actions to foster } \\
\text { entrepreneurial capital development in innovation ecosystems. }\end{array}$ \\
\hline $\begin{array}{l}\text { University-based } \\
\text { organisational } \\
\text { units }\end{array}$ & $\begin{array}{l}\text { What are the characteristics and } \\
\text { working models of the } \\
\text { university-based organisational } \\
\text { units aimed at fostering } \\
\text { entrepreneurial and } \\
\text { innovative ecosystems? }\end{array}$ & $\begin{array}{l}\text { (RQ1) What are the forms of partnerships with universities } \\
\text { in innovation ecosystems and what are the specific } \\
\text { university-based organisational units to manage } \\
\text { these relationships? } \\
\text { (RQ2) To what extent are the features of innovation } \\
\text { ecosystems and characteristics as well as the activities of } \\
\text { university-based organisational units interrelated? } \\
\text { (RQ3) What are the factors affecting the success of } \\
\text { university-based organisational units to foster } \\
\text { entrepreneurial and innovation capabilities in } \\
\text { innovation ecosystems? }\end{array}$ & $\begin{array}{l}\text { (ii) } \\
\text { (iii) }\end{array}$ & $\begin{array}{l}\text { Definition of a taxonomy of the partnerships with universities } \\
\text { ranging from ad hoc relationships to structured partnerships and } \\
\text { classification of the university-based organisational units } \\
\text { supporting university-industry relations; } \\
\text { Identification of the critical factors affecting university-based } \\
\text { organisational units' relationships with companies of an } \\
\text { innovation ecosystem; } \\
\text { Understanding of the activities and key strategic programs } \\
\text { managed by university-based organisational units to foster the } \\
\text { development of entrepreneurial and innovative capabilities of } \\
\text { innovation ecosystems. }\end{array}$ \\
\hline $\begin{array}{l}\text { Company's } \\
\text { capacity for } \\
\text { strategic } \\
\text { partnership with } \\
\text { universities }\end{array}$ & $\begin{array}{l}\text { What are the organisational } \\
\text { models and factors affecting a } \\
\text { company's capacity for } \\
\text { establishing successful } \\
\text { partnerships with universities for } \\
\text { the development of } \\
\text { entrepreneurial and } \\
\text { innovative capabilities? }\end{array}$ & $\begin{array}{l}\text { (RQ1) What are the organisational factors enabling and } \\
\text { hampering the development of the entrepreneurial and } \\
\text { innovative capacity of the companies of an } \\
\text { innovation ecosystem? } \\
\text { (RQ2) How do we structure successful university-company } \\
\text { collaborative relationships to support an organisation's } \\
\text { entrepreneurial and innovative capacity development? } \\
\text { (RQ3) What are the organisational models distinguishing } \\
\text { successful university-industry partnerships? }\end{array}$ & $\begin{array}{l}\text { (i) } \\
\text { (ii) }\end{array}$ & $\begin{array}{l}\text { Identification of the key characteristics and dimensions of the } \\
\text { entrepreneurial and innovative development of the companies } \\
\text { within innovation ecosystems; } \\
\text { Understanding of the factors and variables enabling companies } \\
\text { to establish successful partnerships with universities to support } \\
\text { strategies and initiatives of entrepreneurial and } \\
\text { innovative development; } \\
\text { Taxonomy of the organisational models distinguishing } \\
\text { successful collaborative university-industry partnerships. }\end{array}$ \\
\hline $\begin{array}{l}\text { Designing and } \\
\text { managing } \\
\text { initiatives }\end{array}$ & $\begin{array}{l}\text { What is a framework to support } \\
\text { universities and companies in } \\
\text { managing and evaluating } \\
\text { partnership initiatives for the } \\
\text { development of entrepreneurial } \\
\text { and innovative capabilities? }\end{array}$ & $\begin{array}{l}\text { (RQ1) How can universities and companies of an } \\
\text { innovation ecosystem design partnership initiatives to } \\
\text { support the development of entrepreneurial and } \\
\text { innovative capabilities? } \\
\text { (RQ2) How can university-industry partnerships for the } \\
\text { development of companies' entrepreneurial and innovative } \\
\text { capabilities be managed? } \\
\text { (RQ3) What are the approaches and models to assess the } \\
\text { quality and impact of university-company partnerships? }\end{array}$ & $\begin{array}{l}\text { (i) } \\
\text { (ii) } \\
\text { (iii) }\end{array}$ & $\begin{array}{l}\text { Definition of a strategic model for designing } \\
\text { university-company partnership initiatives; } \\
\text { Outline of a performance measurement system and a set of } \\
\text { indicators useful for assessing universities' activities for } \\
\text { innovation ecosystem development; } \\
\text { Definition of a model to manage university-based initiatives for } \\
\text { the entrepreneurial and innovative development of the } \\
\text { companies of an innovation ecosystem. }\end{array}$ \\
\hline
\end{tabular}




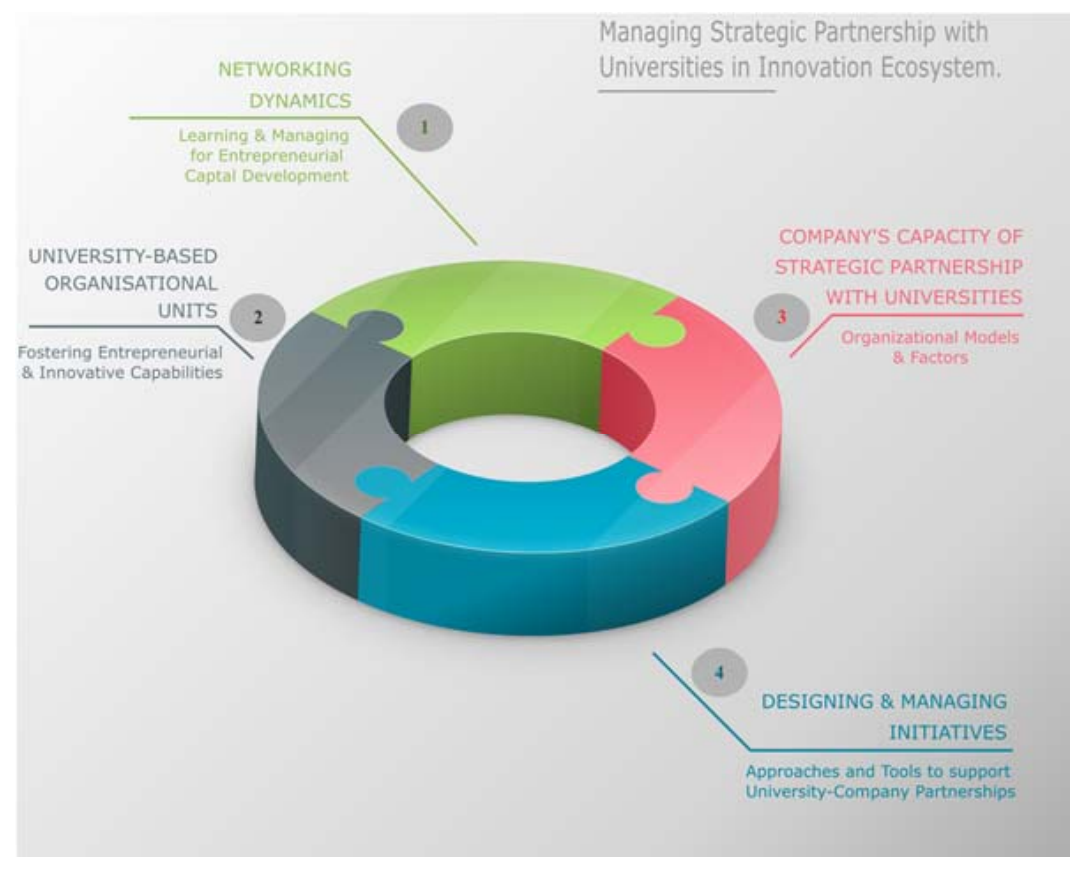

Figure 1. Managing Strategic Partnerships with Universities in Innovation Ecosystems.

This also involves the understanding of the forms of engagement between start-ups and innovation ecosystems that universities can promote and facilitate. Companies can engage with start-up firms through different ways. On the basis of the nature of the start-up enterprises, universities can support identification and connection with student-led start-ups (for example, by means of business plan competitions or student accelerators) with lab-based start-ups, where the relation has to take into account consideration of intellectual property and the engagement of faculty members, and with proto-startups, i.e., student teams working on innovation ideas.

The second perspective, "University-based organisational units", refers to the role and features of the university-based organisational units to foster companies' entrepreneurial and innovative development in innovation ecosystems. Universities are important catalysers of the development of innovation ecosystems, contributing not only to the generation and diffusion of scientific and technological knowledge, but also to the different mechanisms of local innovation processes by stimulating entrepreneurship (e.g., through entrepreneurship education programs, promoting and supporting start-ups and spin-offs), supporting technology transfer (e.g., through collaborative R\&D projects), and facilitating the creation and growth of new knowledge-intensive entrepreneurship ventures (e.g., through acceleration and incubation programs). Universities have set up stable organisational units, such as Liaison Offices, Academic Incubators, Technology Transfer Offices, and, more recently, Entrepreneurship Centres, with the ultimate goal of facilitating innovation processes in innovation ecosystems. These university-based organisational units may have different aims and specialisations, but are basically focused on managing inbound and outbound knowledge flows in order to increase the entrepreneurial and innovative capabilities both in the academic institution and in the innovation ecosystem. Different formats of collaboration can be established. The selection of the right collaboration format is critical for the success of the partnerships with universities. Companies sponsoring research projects represent the traditional format. However, in the last years, a variety of formats have been explored and deployed by companies and universities seeking the establishment of more effective collaborations within local innovation ecosystems. The collaboration format depends on the targeted goals of the university-company collaboration.

The third research perspective, "Company's capacity for strategic partnership with universities", refers to the organisational models and factors affecting a company's capacity for establishing 
successful partnerships with universities in order to develop entrepreneurial and innovative capabilities. The focus is on the organisational models and factors that can strengthen the role played by universities in facilitating the development of successful entrepreneurial and innovation ecosystems through the establishment of successful partnerships with companies, in terms of sustaining the existing entrepreneurial community and stimulating the creation of new entrepreneurial firms, enhancing the innovativeness of the entrepreneurial ecosystem, advancing knowledge flows, and contributing to the sustainability of innovation ecosystems. This involves an understanding of the value goals characterising the partnerships with universities. Companies of an innovation ecosystem can be motivated by a wide range of reasons to engage in collaborations with universities. For this reason, the definition of an innovation value map to identify and support the articulation of the organisations' wants, needs, and expectations is important.

This analysis also involves the understanding of what kind of specific benefits organisations are looking for from the collaboration with universities and, then, the structured approach that can help companies to assess the organisational models and factors affecting their relationships with universities.

The fourth research perspective, "Designing and managing initiatives" focuses on the approaches, models, and tools that can support universities and companies to design, implement, and assess partnership initiatives to foster the development of entrepreneurial and innovative capabilities. The attention is on the understanding of how to design and manage strategic partnerships among universities and companies as well as how to assess universities' activities to support entrepreneurial and innovative development capacities of companies. The aim is to identify performance systems and metrics relevant to support how university-company partnership initiatives can be strategically managed and evaluated.

\section{The Research Methodology and Empirical Investigation}

The establishment of structured relationships with universities in innovative ecosystems is an emerging phenomenon. Therefore, in order to investigate the suggested research questions, it is fundamental to adopt a grounded theory-based approach and to clearly define the characteristics and dimensions of the empirical context of analysis. The attention has to be focused first on the identification of the key variables, assumptions, conceptual perspectives, frameworks, experiences, and management implications of the relationships of universities with companies in innovation ecosystems.

Desk research as well as the use of secondary data resources and the analysis of best-case examples can provide an outline of the features and dimensions of existing best practices of companies' partnerships with universities. A deductive analysis has to be integrated with an inductive one with the aim of empirically investigating the companies' collaborative relationships with universities in innovation ecosystems located in specific geographical areas, such as, for example, southern Italy. This analysis has to take into account the actual practices of university-company collaborations.

Finally, the suggested integrated model has to be tested. For this reason, an experimentation-based approach can be adopted focusing on the so-called "Contamination Labs-CLabs". A Contamination $\mathrm{Lab}$ is a university centre with two fundamental purposes. On the one hand, it aims to create an educational environment, which can be relational, physical, and virtual, and to support learning dynamics for the development of entrepreneurial capital as well as an entrepreneurship and innovation culture. On the other hand, it facilitates and supports the development of collaborations for innovation through a wide range of forms of relationships including idea labs; innovation consortiums; "workbenches" to solve short-term, incremental problems; project sponsorship; innovation programs; collaborative research programs; alliances; start-up creation; research translation; search funding mechanisms for innovation projects; and so on.

The choice of analysing CLabs is motivated by the fact that these centres can play an important role in local innovation ecosystems. They support the move from an "ad hoc approach", in which university collaborations are first and foremost established by individual researchers with a focus on specific university-company collaboration projects, to "strategic ecosystem partnerships". In the "ad 
hoc approach", the collaborations are based on personal experience and the relations of the researchers and executives of an organisation. The rationale for the collaboration is the personal familiarity between individuals, not between the university and the company. "Ad hoc approaches" often lead to a large number of collaborations but with little synergy [3]. On the contrary, the adoption of "strategic ecosystem partnerships" requires that both enterprises and universities place infrastructure for university-industry interactions and deploy management models and tools. This can result in more effective and continuous innovation processes.

\section{Final Discussion and Conclusions}

This paper proposes a research agenda for the advancement of knowledge about how to develop and manage university-company partnerships in innovation ecosystems. It outlines the open research challenges in the management literature in relation to the understanding of how universities and companies can effectively establish, implement, manage, and evaluate collaborative relationships in order to develop entrepreneurial and innovative capabilities. Four main research perspectives have been introduced and discussed with the scope of delineating the key dimensions characterising the definition of a holistic and integrated model distinguishing the key factors, variables, and dimensions to take into account when strategically analysing partnerships with universities for both descriptive and normative purposes.

It is possible to identify a number of reasons for the relevance of such model. It would support the following managerial actions: (i) taking better advantage of the regional, national, and international schemes/programs and incentives to spur entrepreneurship and innovation, through the management of more effective university-industry relationships; (ii) devising better policies to support partnerships with universities that can be effectively translated into impacts for local development; (iii) establishing and managing potential successful university-company partnerships that, in turn, drive the growth of entrepreneurial and innovative ecosystems, particularly taking into account the specific characteristics of the local context in which they are embedded; (iv) making universities that show a limited and marginal role in the development of an entrepreneurial and innovative ecosystem more proactive; (v) enhancing local entrepreneurial and innovative capabilities as a critical precondition to reduce or even invert the knowledge diaspora of highly trained graduates and talented people that increasingly emigrate from the regions with social and cultural impoverishment, as well as the loss of human resources and competence; (vi) developing new governance bodies and organisational units in universities to support entrepreneurship and innovation development; (vii) enforcing and diffusing an entrepreneurial and innovative culture and behaviours that enhance employability; (viii) using approaches and tools to inform analysis and design initiatives to foster the development of companies' entrepreneurial and innovative capabilities.

Author Contributions: The individual contributions of authors to the manuscript: G.S.: Sections 3-5. D.C.: Introduction, Section 2 and Final Discussion and Conclusions. Both authors read and approved the final manuscript.

Funding: This paper was supported by SOItmC and DGIST in the publishing fee (DGIST-IT-18-01).

Acknowledgments: This paper was presented as a keynote speech at SOItmC 2018, and the publishing fee was supported by DGIST (DGIST-IT-18-01).

Conflicts of Interest: The authors declare no conflicts of interest.

\section{References}

1. Barnett, R. The Ecological University: A Feasible Utopia; Taylor \& Francis Ltd.: London, UK, 2017.

2. Dougherty, D. Taking advantage of emergence for complex innovation eco-systems. J. Open Innov. Technol. Mark. Complex. 2017, 33, 14. [CrossRef]

3. Frølund, L.; Murray, F.; Riedel, M. Developing Successful Strategic Partnerships with Universities. MIT Sloan Manag. Rev. 2018, 59, 71-79. 
4. Malerba, F. Knowledge-Intensive Entrepreneurship and Innovation Systems. Evidence from Europe; Routledge: London, UK; New York, NY, USA, 2010.

5. Perkmann, M.; Salter, A. How to create productive partnerships with universities. MIT Sloan Manag. Rev. 2012, 53, 79. [CrossRef]

6. Mercan, B.; Göktas, D. Components of Innovation Ecosystems: A Cross-Country Study. Int. Res. J. Financ. Econ. 2011, 76, 102-112.

7. Maassen, P.; Stensaker, B. The Knowledge triangle: European higher education policy logics and policy implications. High. Educ. 2011, 61, 757-769. [CrossRef]

8. Etzkowitz, H. The evolution of the entrepreneurial university. Int. J. Technol. Glob. 2004, 1, 64-77. [CrossRef]

9. Leydesdorff, L.; Ivanova, I. “Open innovation" and "triple helix" models of innovation: Can synergy in innovation systems be measured? J. Open Innov. Technol. Mark. Complex. 2016, 11. [CrossRef]

10. Ranga, M.; Hoareau, C.; Durazzi, N.; Etzkowitz, H.; Marcucci, P.; Usher, A. Study on University-Business Cooperation in the US; EU Bookshop: Luxembourg, 2013.

11. Romano, A.; Passiante, G.; Del Vecchio, P.; Secundo, G. The Innovation Ecosystem as Booster for the Innovative Entrepreneurship in the Smart Specialization Strategy. Int. J. Knowl.-Based Dev. 2014, 5, 271-288. [CrossRef]

12. Dess, G.G.; Ireland, R.D.; Zahra, S.A.; Floyd, S.W.; Janney, J.J.; Lane, P.J. Emerging issues in corporate entrepreneurship. J. Manag. 2003, 29, 351-378.

13. Venkataraman, S. Regional Transformation through Technological Entrepreneurship. J. Bus. Ventur. 2004, 19, 153-167. [CrossRef]

14. Etzkowitz, H.; Leydesdorff, L. The dynamics of innovation: From national systems and 'Mode 2' to a triple helix of university-industry-government relations. Res. Policy 2000, 29, 109-123. [CrossRef]

15. Nambisan, S.; Lyytinen, K.; Majchrzak, A.; Song, M. Digital innovation management: Reinventing innovation management research in a digital world. MIS Q. 2017, 41, 223-238. [CrossRef]

16. Yoo, Y.; Henfridsson, O.; Lyytinen, K. Research commentary-The new organizing logic of digital innovation: An agenda for information systems research. Inf. Syst. Res. 2010, 21, 724-735. [CrossRef]

17. Allen, K. Entrepreneurship for Scientist and Engineer; Prentice Hall: Upper Saddle River, NJ, USA, 2009.

18. Byers, T.; Dorf, R.; Nelson, A. Technology Ventures: From Idea to Enterprise; McGraw-Hill Education: New York, NY, USA, 2010.

19. Lumpkin, G.T.; Dess, G.G. Clarifying the entrepreneurial orientation construct and linking it to performance. Acad. Manag. Rev. 1996, 21, 135-172. [CrossRef]

20. Ratinho, T.; Harms, R.; Walsh, S. Structuring the Technology Entrepreneurship publication landscape: Making sense out of chaos. Technol. Forecast. Soc. Chang. 2015, 100, 168-175. [CrossRef]

21. Villani, E.; Linder, C.; Grimaldi, R. Effectuation and Causation in Science-based New Venture Creation: A Configurational Approach. J. Bus. Res. 2018, 83, 173-185. [CrossRef]

22. Foray, D.; David, P.A.; Hall, B.H. Smart Specialisation from Academic Idea to Political Instrument, the Surprising Career of a Concept and the Difficulties Involved in Its Implementation; EPFL: Lausanne, Switzerland, 2011.

23. Schumpeter, J.A. Change and the Entrepreneur. In Essays of JA Schumpeter; Harvard University Press: Cambridge, MA, USA, 1934.

24. Schumpeter, J.A. The creative response in economic history. J. Econ. Hist. 1947, 7, 149-159. [CrossRef]

25. Mian, S.; Lamine, W.; Fayolle, A. Technology Business Incubation: An overview of the state of knowledge. Technovation 2016, 50, 1-12. [CrossRef]

26. Finkle, T.A.; Menzies, T.V.; Kuratko, D.F.; Goldsby, M.G. An examination of the financial challenges of entrepreneurship centers throughout the world. J. Small Bus. Entrep. 2013, 26, 67-85. [CrossRef]

27. Maas, G.; Jones, P. The role of entrepreneurship centers. In Title of Entrepreneurship Centres: Global Perspectives on Their Contributions to Higher Education Institutions; Maas, G., Jones, P., Eds.; Palgrave Macmillan: Basingstoke, UK, 2017.

28. Nelles, J.; Vorley, T. Entrepreneurial architecture: A blueprint for entrepreneurial universities. Can. J. Adm. Sci. 2011, 28, 341-353. [CrossRef]

29. Bischoff, K.; Volkmann, C.K.; Audretsch, D.B. Stakeholder collaboration in entrepreneurship education: An analysis of the entrepreneurial ecosystems of European higher educational institutions. J. Technol. Transf. 2018, 43, 20-46. [CrossRef]

30. Isenberg, D.J. How to start an entrepreneurial revolution. Harv. Bus. Rev. 2010, 88, 40-50. 
31. Nambisan, S.; Baron, R.A. Entrepreneurship in innovation ecosystems: Entrepreneurs' self-regulatory processes and their implications for new venture success. Entrep. Theory Pract. 2013, 37, 1071-1097. [CrossRef]

32. Wright, M.; Siegel, D.S.; Mustar, P. An emerging ecosystem for student start-ups. J. Technol. Transf. 2017, 42, 909-922. [CrossRef]

33. Chesbrough, H. Open Innovation: The New Imperative for Creating and Profiting from Technology; Harvard Business School: Boston, MA, USA, 2006.

34. Erikson, T. Entrepreneurial capital: The emerging venture's most important asset and competitive advantage. J. Bus. Ventur. 2002, 17, 275-290. [CrossRef]

(C) 2018 by the authors. Licensee MDPI, Basel, Switzerland. This article is an open access article distributed under the terms and conditions of the Creative Commons Attribution (CC BY) license (http://creativecommons.org/licenses/by/4.0/). 